\title{
Physiological and morphological characterisation of Limonium species in their natural habitats: Insights into their abiotic stress responses
}

\author{
Sara González-Orenga • Josep V. Llinares • Mohamad \\ Al Hassan • Ana Fita • Francisco Collado • \\ Purificación Lisón • Oscar Vicente • Monica Boscaiu
}

Received: 11 September 2019 / Accepted: 5 March 2020 / Published online: 14 March 2020

(C) Springer Nature Switzerland AG 2020

\begin{abstract}
Background and aims Morphological and biochemical traits of four halophytes of the genus Limonium were analysed in plants sampled from salt marshes in SE Spain. This work aimed to explore the mechanism(s) behind the adaptation of these species to stressful habitats, with particular emphasis on responses to drought.
\end{abstract}

Responsible Editor: Hans Lambers.

Electronic supplementary material The online version of this article (https://doi.org/10.1007/s11104-020-04486-4) contains supplementary material, which is available to authorized users.

S. González-Orenga · J. V. Llinares · M. Boscaiu Mediterranean Agroforestry Institute (IAM, UPV), Universitat Politècnica de València, Camino de Vera 14, 46022 Valencia, Spain

M. Al Hassan · P. Lisón

Institute for Plant Molecular and Cell Biology (UPV-CSIC), Universitat Politècnica de València, Camino de Vera 14, 46022 Valencia, Spain

M. Al Hassan

Wageningen UR Plant Breeding, Wageningen University and Research Centre, Wageningen, Netherlands

A. Fita $\cdot$ O. Vicente $(\bowtie)$

Institute for the Preservation and Improvement of Valencian Agrodiversity (COMAV, UPV), Universitat Politècnica de València, Camino de Vera 14, 46022 Valencia, Spain e-mail: ovicente@upvnet.upv.es

F. Collado

Servici Devesa-Albufera, Vivers Municipals de El Saler, CV-500, $\mathrm{km} \mathrm{8.5,} 46012$ Valencia, Spain
Methods Plants of each species together with soil samples were collected in summer, which is the most stressful season in the Mediterranean. Soil parameters and plant morphological traits were determined, and the levels of several biochemical stress markers in plants were measured using spectrophotometric assays. A multivariate analysis was performed to correlate soil and plant data.

Results Morphological characteristics regarding the underground system topology and several biochemical traits (higher foliar $\mathrm{Ca}^{2+}$, sucrose and glucose, and lower proline, glycine-betaine and fructose) clearly separate L. santapolense individuals from plants of the other three species.

Conclusions Drought tolerance of $L$. santapolense in the field is mostly dependent on morphological adaptations: when growing in an arid location, plants of this species develop long taproots that can extract water from the deep, moist layers of the soil.

Keywords Antioxidants - Climate change · Drought . Endemics · Osmolytes · Salt marshes · Soil analysis

Abbreviations
$\begin{array}{ll}\text { ETo } & \text { potential evapotranspiration } \\ \text { S } & \text { sand } \\ \text { Sl } & \text { silt } \\ \text { C } & \text { clay } \\ \text { OM } & \text { organic matter } \\ \text { ECsat } & \text { electric conductivity in the saturation extract } \\ \text { NS } & \text { number of apical shoots } \\ \text { NL } & \text { number of leaves }\end{array}$




$\begin{array}{ll}\text { SFW } & \text { Shoot fresh weigh } \\ \text { RFW } & \text { Root fresh weight } \\ \text { LA } & \text { total leaf area } \\ \text { RL } & \text { total root length } \\ \text { LRL } & \text { lateral root length } \\ \text { PRL } & \text { taproot or principal root length } \\ \text { RSA } & \text { root surface area } \\ \text { D } & \text { average diameter of the roots } \\ \text { R/S } & \text { root to shoot ratio } \\ \text { SRL } & \text { specific root length } \\ \text { M } & \text { root magnitude } \\ \text { a } & \text { root altitude } \\ \text { Nd } & \text { numbers of root nodes } \\ \text { TI } & \text { topological index } \\ \text { Pro } & \text { proline } \\ \text { GB } & \text { glycine betaine } \\ \text { TSS } & \text { total soluble sugars } \\ \text { Fru } & \text { fructose } \\ \text { Suc } & \text { sucrose } \\ \text { Glu } & \text { glucose } \\ \text { MDA } & \text { malondialdehyde } \\ \text { DPPH } & \text { 2,2-diphenyl-1-picrylhydrazyl } \\ \text { TPC } & \text { total phenolic compounds } \\ \text { TF } & \text { total flavonoids } \\ \text { PCA } & \text { Principal component analysis } \\ & \end{array}$

\section{Introduction}

Salt marshes, like many other coastal habitats, are considered as highly threatened ecosystems, intensively modified by anthropogenic actions (Barbier et al. 2011). In the Iberian Peninsula, as in many other regions of the world, these habitats have suffered numerous threats. Considered as insalubrious in the past, they were eliminated when located near human settlements; expansion of agriculture and touristic pressure also contributed to their reduction. In addition, effects of climate change represent another threat for salt marshes in the Mediterranean area. Not only rises of temperature and the risk of longer and more intense drought periods but also the sudden alteration of seasonal weather patterns may modify the existing conditions in these ecosystems (Thorne et al. 2012). The characteristic vegetation of the salt marshes is represented mainly by halophytic plants, which are tolerant to soil salinity in a greater or lesser degree. There is a wide range of halophytes, from plants present at the borders of salt marshes and adapted to only (relatively) low salinity levels, to plants that show optimal growth under moderate saline conditions and tolerate salt concentrations even higher than that of seawater. It is not possible to define a precise salinity threshold to separate halophytes from glycophytes, as plant species show a continuous range of sensitivity to salt stress (Grigore and Toma 2017). Nevertheless, a generally accepted, operational definition is that halophytes are plants of natural saline environments, which are able to complete their life cycle at soil salinities equivalent to, at least, $200 \mathrm{mM} \mathrm{NaCl}$ (Flowers and Colmer 2008). However, salinity is not the only limiting factor for plants in salt marshes, where they are simultaneously affected by other additional stressful conditions. For example, plants growing in such habitats under Mediterranean climatic conditions have to switch from waterlogging, after heavy rains in spring, to extremely dry conditions in summer, when the soil surface is covered by a crust of salt due to intense evapotranspiration (Álvarez-Rogel et al. 1997, 2000). Responses to one or the other type of stress broadly vary among different genera of plants and often even between congener species.

A useful approach for unravelling the mechanisms underlying plant tolerance to salt - and other abiotic stresses - is to study the responses to stress of taxonomically (implicitly, also genetically) related taxa. A good candidate for this type of comparative studies is the genus Limonium L. of the Plumbaginaceae family. This genus includes more than 400 species, many of which are halophytes, and are well represented in the Mediterranean (Greuter et al. 1989) with numerous endemics in the area of study (Mateo and Crespo 2014).

Four species of Limonium have been selected for our ongoing research on this genus: L. santapolense Erben, L. girardianum (Guss.) Fourr., L. virgatum (Willd.) Fourr. and L. narbonense Mill. The four species flower in summer, L. santapolense from May to July and the other three from July to September. Regarding their geographic distribution, L. santapolense is a local endemic, present only on littoral sandy substrates in a small area in the province of Alicante, whereas L. girardianum is endemic to $\mathrm{S}$ France, E Spain and Balearic Isles, growing on sandy coasts and cliffs. L. virgatum and L. narbonense have a broader distribution throughout the Mediterranean region, the first on sandy beaches and rocky coasts, reaching the Middle East and North of Africa, and the second in salt marshes throughout the Mediterranean, in Spain also on the 
Atlantic coast (Erben 1993). Besides the conservation value of the two endemic species, all four are important elements of the salt marsh ecosystems as their presence and frequency in plant communities increase the diversity and the degree of differentiation between the local habitats in the area of study. Populations of the four species growing in the wild in SE Spain have not been studied in depth so far, and their morphological and biochemical traits may reflect local adaptations. Thus, their analysis is important not only for obtaining a broader knowledge of the four species, but also to predict their possible future response to the challenge of climate change.

We have previously analysed the germination patterns of these species (Monllor et al. 2018), and their responses to salt stress (Al Hassan et al. 2017) and water stress (González-Orenga et al. 2019) under controlled greenhouse conditions. Tolerance to salinity was similar in the four species and was mainly based on the active transport and accumulation of ions in the leaves, with the concomitant synthesis of soluble sugars and proline as compatible solutes for osmotic adjustment (Al Hassan et al. 2017). In contrast, water stress, induced by withholding irrigation of the plants, affected mostly L. santapolense, which appeared to be highly sensitive to dehydration - plants lost about one-third of their fresh weight after the water deficit treatment (GonzálezOrenga et al. 2019). This finding was somewhat surprising since the natural habitat of this species is drier than those of the plants of the other three taxa analysed. Our working hypothesis to explain this apparent discrepancy is that $L$. santapolense plants possess some specific mechanisms that enable their survival in the field, under harsh natural conditions with very little water availability, but that cannot be mimicked in pot experiments in the artificial environment of a greenhouse. The analysis of plants sampled in the wild, in correlation with the climatic and edaphic conditions at the sampling sites, represents a useful complementary approach to study the stress response mechanisms of the four Limonium species, considering that the specific distribution of each taxon, within the same general habitat, may depend on local variations of soil characteristics.

With these ideas in mind, we undertook the present study on the mechanisms of stress tolerance in the selected Limonium species, with the following specific aims: (i) to analyse the climatic and soil conditions at the sampling sites of each species; (ii) to study the growth patterns of plants of the four species in the wild; (iii) to study stress response mechanisms based on the regulation of ion transport and osmolytes accumulation; and (iv) to determine the levels of oxidative stress affecting the plants, and the concentrations of representative nonenzymatic antioxidants.

\section{Material and methods}

Sampling sites and material sampling

Mature plants of $L$. santapolense, a rare endemic restricted to the province of Alicante (SE Spain), were collected from Clot de Galvany, a saltmarsh located near the city of Elche $\left(39^{\circ} 15^{\prime} \mathrm{N} / 0^{\circ} 31^{\prime} \mathrm{W}\right)$. Plants of the other three species were collected from 'La Albufera' Natural Park, near the city of Valencia (39 $20^{\circ} \mathrm{N} / 0^{\circ} 19^{\prime}$ $\mathrm{W})$. Limonium At the sampling sites of the four species, four whole plants of each species and three soil samples were collected in July 2018.

\section{Climatic analysis}

Climatic data were obtained from the nearest meteorological stations (Elche for 'Clot de Galvany' and Benifaió for El Saler), provided by the Agroclimatic Information System for Irrigation (SIAR 2018), of the Spanish Ministry of Environment, Rural and Marine Affairs (MARM). The following bioclimatic indexes were calculated using available meteorological data of the last 16 years:

- $\quad$ TI: Thermicity index, $\mathrm{TI}=10 *(\mathrm{~T}+\mathrm{M}+\mathrm{m})$

- CI: Continentality index, $\mathrm{CI}=\mathrm{T} \max -\mathrm{T} \min$

- OI: Ombrothermic index, OI $=(\mathrm{P} / 12) * 10 / \sum \mathrm{Tm}$

- Ppv: Summer precipitation in $\mathrm{mm}$ of the three consecutive warmest months in the year.

- Ttv: Value in tenths of degree resulting from the sum of the monthly average temperatures of the three consecutive warmest months in the year.

- ETo: Potential evapotranspiration, calculated according to Penman-Monteith equation (Allen et al. 1998).

- GI: Giacobbe index, GI = (P June + P July + PAugust $) / T^{a}$ of the warmest month

where: $\mathrm{T}$, yearly average temperature; $\mathrm{m}$, average temperature of the minima of the coldest month of the year; $M$, average temperature of the maxima of the 
coldest month of the year; $\mathrm{T}$ max, average temperature of the warmest month; $\mathrm{T}$ min, average temperature of the coldest month; Tm, average temperature of each month; P, total yearly precipitation.

All indexes were calculated according to Rivas-Martínez and Rivas-Saenz (1996-2018), except for GI calculated according to Giacobbe $(1938,1959)$.

These specific indexes were chosen as they are the most suitable for local differentiations within the Mediterranean climate type (Ferriol et al. 2006).

Meteorological data (mean, maximum and minimum temperatures, rainfall, air humidity and evapotranspiration) of the previous month to sampling were obtained from the same source.

Soil analysis

Soil samples were taken at a depth of $0-15 \mathrm{~cm}$. Once the samples were air dried at room temperature (approx. $25^{\circ} \mathrm{C}$ ), they were crushed with a roller to break aggregates and then passed through a $2-\mathrm{mm}$ sieve. Analyses were performed on fine soil (diameter $<2 \mathrm{~mm}$ ). Soil texture was analysed by the hydrometer method (Bouyoucos 1962), organic matter content (OM\%) was determined as described by Walkley and Black (1934), and carbonates were measured with a Bernard Calcimeter.

The following parameters were determined in soil saturation extracts: $\mathrm{pH}$, electric conductivity (EC), and concentrations of cations $\left(\mathrm{Na}^{+}, \mathrm{K}^{+}, \mathrm{Ca}^{2+}\right.$ and $\left.\mathrm{Mg}^{2+}\right)$ and chlorides. A Crison pH-meter Basic 20 and a Crison Conductimeter Basic 30 were used to measure $\mathrm{pH}$ and $\mathrm{EC}$, respectively. Sodium and potassium were quantified with a PFP7 flame photometer (Jenway Inc., Burlington, VT, USA), chlorides were measured in a MKII Chloride Analyzer 926 (Sherwood, Inc., Cambridge, UK), and divalent cations of calcium and magnesium were measured with an atomic absorption spectrometer SpectrA 220 (Varian, Inc., CA, USA). Cation exchange capacity (CEC) was determined following Rhoades (1982).

Plant sampling in the wild

Four plants were selected from distant areas of their natural location and then uprooted as described in Fita et al. (2013), trying to recover intact roots systems. Roots were excavated digging a $30 \mathrm{~cm}$ depth-pit $50 \mathrm{~cm}$ away from the plant shoot without breaking any roots that grew horizontally further than those $50 \mathrm{~cm}$ and then removing carefully the soil, as if it was in a pot. If roots grew deeper, the same procedure was repeated until reaching the end of the root. The number of shoots per plant (NS), number of leaves (NL), shoot fresh weight (SFW), and root fresh weight (RFW) were recorded. The roots were scanned (Epson LA 1600+, Epson America Inc. Long Beach, CA, USA,), and the pictures were analysed with the WinRhizo Pro software (WinRhizo Pro 2003b, Reagent Instruments Inc. Quebec Canada) to obtain the total root length (RL, cm), the lateral root length $(\mathrm{LRL}, \mathrm{cm})$, the primary root length $(\mathrm{PRL}, \mathrm{cm})$, the root surface area $\left(\mathrm{RSA}, \mathrm{cm}^{2}\right.$ ) and the average diameter of the roots $(\mathrm{D}, \mathrm{mm})$.

To better assess the root architecture, the root topological parameters defined by Fitter (1987) were evaluated. Root magnitude (M) was evaluated as the number of external links of a root, root altitude (a), as the maximum external path length of the root, numbers of root nodes $(\mathrm{Nd})$ were counted, and the topological index (TI) was calculated as the ratio of log altitude over $\log$ magnitude (Magalhães and Seifert 2015). Other composite parameters were calculated, such as root to shoot ratio $(\mathrm{R} / \mathrm{S})$ as $\mathrm{RFW} / \mathrm{SFW}$, and the specific root length (SRL, cm/g) as RL/RFW.

A fraction of the plant material was stored at $-20{ }^{\circ} \mathrm{C}$, and the remaining material was dried for several days in an oven at $65^{\circ} \mathrm{C}$ until constant weight. Water contents (WC\%) were expressed as percentages of fresh weight, in roots and leaves.

\section{Ion concentration measurements}

Ion concentrations were determined in dry roots and leaves, after being eluted in aqueous extracts according to Weimberg (1987), by heating the samples $(0.05 \mathrm{~g}$ of dried, ground plant material in $15 \mathrm{~mL}$ of water) for $15 \mathrm{~min}$ at $95{ }^{\circ} \mathrm{C}$, followed by filtration through a $0.45 \mu \mathrm{m}$ filter (Gelman Laboratory, PALL Corporation). Ion $\left(\mathrm{Na}^{+}, \mathrm{K}^{+}, \mathrm{Cl}^{-}, \mathrm{Ca}^{2+}, \mathrm{Mg}^{2+}\right)$ concentrations in plant extracts were measured using the same instruments as for their determination in soil samples.

\section{Osmolyte quantification}

Proline (Pro) was extracted with $2 \mathrm{~mL}$ of $3 \%(w / v)$ sulfosalicylic acid, from $0.05 \mathrm{~g}$ of dry leaf material, and was quantified in toluene according to the acidninhydrin method of Bates et al. (1973). The extract, 
mixed with acid ninhydrin, was heated at $95{ }^{\circ} \mathrm{C}$ for one $\mathrm{h}$, cooled on ice and extracted with toluene. The absorbance of the organic phase was measured at $520 \mathrm{~nm}$, using toluene as a blank. Pro concentrations were expressed as $\mu \mathrm{mol} \mathrm{g}{ }^{-1} \mathrm{DW}$.

Glycine betaine $(\mathrm{GB})$ was extracted from $0.05 \mathrm{~g}$ dry leaf material with $1 \mathrm{~mL}$ water, according to Grieve and Grattan (1983) with the modifications proposed by Nawaz and Ashraf (2010). The extract was supplemented with potassium iodide, kept on ice for $90 \mathrm{~min}$ and then extracted with 1, 2-dichloroethane (pre-cooled at $-20{ }^{\circ} \mathrm{C}$ ); finally, the absorbance of the sample was measured at $365 \mathrm{~nm}$. GB concentration was expressed as $\mu \mathrm{mol} \mathrm{g}{ }^{-1} \mathrm{DW}$.

Total soluble sugars (TSS), were measured in $0.05 \mathrm{~g}$ dry plant material extracted with $2 \mathrm{~mL}$ of $80 \%(v / v)$ methanol, following the method described by Dubois et al. (1956). The sample was mixed on a rocker shaker for $24 \mathrm{~h}$; the extract was then centrifuged, concentrated sulfuric acid and 5\% phenol was added to the supernatant, and the absorbance was measured at $490 \mathrm{~nm}$. TSS concentrations were expressed as 'mg equivalent of glucose' (used as the standard) per g DW.

\section{HPLC analysis of soluble carbohydrates}

Plant dry material $(0.05 \mathrm{~g})$ was boiled in $2 \mathrm{~mL}$ MilliQ water for $10 \mathrm{~min}$ and then filtered through $0.22 \mu \mathrm{m}$ nylon filters. The soluble sugar fraction was analysed using a Waters 1525 high performance liquid chromatography (HPLC) coupled to a 2424 evaporative light scattering detector (ELSD), according to Al Hassan et al. (2016). The source parameters of ELSD were the following: gain 75 , data rate 1 point per second, nebulizer heating $60 \%$, drift tube $50{ }^{\circ} \mathrm{C}$, and gas pressure $2.8 \mathrm{Kg} / \mathrm{cm}^{2}$. The analysis was carried out injecting $20 \mu \mathrm{L}$ aliquots with a Waters 717 auto-sampler into a Prontosil 120-3-amino column $(4.6 \times 125 \mathrm{~mm} ; 3 \mu \mathrm{m}$ particle size $)$ maintained at room temperature. An isocratic flux $(1 \mathrm{~mL} / \mathrm{min})$ of $85 \%$ acetonitrile (J.T.Baker) was applied for $25 \mathrm{~min}$ in each run. Standards of glucose, fructose, and sucrose were employed to identify peaks by co-injection. Sugars were quantified with peak integration using the Waters Empower software and comparison with glucose, fructose, and sucrose standard calibration curves.
Malondialdehyde and total antioxidant activity

Malondialdehyde (MDA, a reliable oxidative stress marker) concentrations were determined in the same $80 \%$ methanol leaf extracts used to quantify TSS, according to the method of Hodges et al. (1999). The extracts were mixed with $0.5 \%$ thiobarbituric acid (TBA) prepared in 20\% TCA (or with 20\% TCA without TBA for the controls), and then incubated at $95{ }^{\circ} \mathrm{C}$ for $15 \mathrm{~min}$. After the reaction was stopped by placing the tubes on ice for a few minutes, absorbance was measured at 600 and $532 \mathrm{~nm}$, and the concentration of MDA was determined using the equation described by Hodges et al. (1999).

The antioxidant activity was evaluated according to Falchi et al. (2006), by measuring the ability of the samples to quench the radical 2,2-diphenyl-1picrylhydrazyl (DPPH), a synthetic and stable free radical product, whose quenching by a scavenger substrate could be followed spectrophotometrically at $517 \mathrm{~nm}$. Leaf dry material $(0.05 \mathrm{~g})$ was extracted using $2 \mathrm{~mL}$ of $90 \%$ methanol by sonication during $10 \mathrm{~min}$. The sample was centrifuged at $14000 \mathrm{rpm}$ for $15 \mathrm{~min}$, and the supernatant was collected. Then, $50 \mu \mathrm{L}$ of this methanol-soluble phenolic fraction was diluted with $2 \mathrm{~mL}$ of $96 \%$ ethanol, $0.5 \mathrm{~mL}$ of the resulting solution was added to $1.5 \mathrm{~mL} 96 \%$ ethanol and $0.5 \mathrm{~mL}$ of an ethanolic solution containing $0.5 \mathrm{mM}$ DPPH. To check the radical stability, a blank sample was prepared without the plant extract. Mixtures were then incubated at $25^{\circ} \mathrm{C}$ for $10 \mathrm{~min}$, and the absorbance was measured at $517 \mathrm{~nm}$.

The radical scavenging activity $(S)$ of each extract was expressed in percentage and calculated as $\mathrm{S}=100$ $-[(\mathrm{Ax} / \mathrm{A} 0) \times 100] ; A_{x}$ is the optical density of the DPPH solution in the presence of the extract, and $A_{0}$ in its absence.

Non-enzymatic antioxidants

Total phenolic compounds (TPC) and total flavonoid (TF) concentrations were determined in $80 \%$ methanol extracts, as for TSS. TPC were measured by its reaction with the Folin-Ciocalteu reagent and sodium bicarbonate, according to Blainski et al. (2013). Absorbance measurements were taken at $765 \mathrm{~nm}$, and TPC concentrations were expressed as equivalents of gallic acid (mg eq. $\mathrm{GA} \mathrm{g}^{-1} \mathrm{DW}$ ). TF was determined according to Zhishen et al. (1999); the extracts were mixed with 
sodium nitrite, and then aluminium chloride was added under alkaline conditions before absorbance was measured at $510 \mathrm{~nm}$. TF concentrations were expressed as equivalents of catechin (mg eq. C. $\mathrm{g}^{-1} \mathrm{DW}$ ).

\section{Statistical analysis}

Statistical analyses were performed using the programme Statgraphics Centurion XVI. Before the analysis of variance, the Shapiro-Wilk test was used to check for validity of normality assumption and the Levene test for the homogeneity of variance. The significance of the effects of stress was evaluated by one way ANOVA. Tukey's HSD test was applied to identify the homogeneous groups when significant differences were found between the studied species. Correlations between soil and biochemical plant parameters were performed by the Pearson product-moment coefficient. Parameters that showed significant correlations were used for a principal component analysis (PCA). A cluster analysis was applied to discriminate the four species based on their growth and biochemical responses to water stress, using Squared Euclidean distances for the proximity procedure. All means throughout the text include the standard error (SE). A dendrogram based on the nearest neighbour method, using squared Euclidian distances between biochemical parameters and ion concentrations, was also performed with Stagraphics Centurion XVI.

\section{Results}

Climatic analysis

Individuals of three of the four Limonium species under study were collected from salt marshes in El Saler, near the city of Valencia, and those of the fourth, L. santapolense, from a more southern location (Clot de Galvany) near Elche, in the province of Alicante. Both areas have a similar climate with the highest temperatures in summer, coinciding with a drastic reduction of rainfall, which is characteristic of the Mediterranean climate. However, the amount of precipitation differs in the two areas; the average annual rainfall is much higher in El Saler than in the Clot area. The mean rainfall calculated for the last 18 years is $240.02 \mathrm{~mm}$ in Clot and $441.66 \mathrm{~mm}$ in El Saler, although ETo is similar in the two zones. The two areas are located near the beach, and therefore have similar Continentality indices, and both are classified within the Thermomediterranean thermotype, characterised by warm temperatures (a yearly mean of $16-18{ }^{\circ} \mathrm{C}$ ) and mild winters, and have very similar thermicity indices (TI) (Table 1). Based on their ombrothermic index calculated according to RivasMartínez and Rivas-Saenz (1996-2018), Clot is classified as arid, and El Saler as semi-arid.

Meteorological data for the four weeks previous to sampling (from 15th of June to 15th of July, 2018) in the two areas, summarised in Table 2, indicate that they differed mainly in the amount of rainfall in the last two weeks of June, which were extremely dry in Clot, but more than $100 \mathrm{~mm}$ were registered in El Saler. As the evapotranspiration was similar in both locations, the water deficit was obviously much more intense at Clot, the sampling area of $L$. santapolense. During the first two weeks of July, the meteorological conditions were similar in the two areas, with a pronounced water deficit, as is characteristic for the Mediterranean climate in summer.

\section{Soil analysis}

The textural classes of the soils were determined according to their corresponding percentages of sand, silt and clay, based on the USDA classification (Soil Survey Division Staff 1993). As shown in Table 3, all

Table 1 Values of the climate variables in the collection sites of Limonium santapolense (Clot) and L. giradianum, L. narbonense and L. virgatum (El Saler)

\begin{tabular}{lll}
\hline Bioclimatic Indexes & Clot & El Saler \\
\hline TI & 406.1 & 389.3 \\
CI & 15.2 & 15.1 \\
OI & 0.9 & 1.6 \\
Ppv & 18.8 & 38.2 \\
Ttv & 74.1 & 73.9 \\
ETo & 97.1 & 98.9 \\
GI & 0.6 & 1.4 \\
\hline
\end{tabular}

Data were obtained from the nearest meteorological stations (Elche for 'Clot de Galvany' and Benifaió for El Saler) and calculated for the period 1999-2018)

$T I$, Thermicity index; $C I$, Continentality index; $O I$, Ombrothermic index; $P p v$, Summer precipitation in $\mathrm{mm}$ of the three consecutive warmest months in the year; $T t$, Value in tenths of degree resulting from the sum of the monthly average temperatures of the three consecutive warmest months in the year; ETo, Evapotranspiration; $I G$, Giacobbe index 
Table 2 Meteorological data in the period previous to the sampling (from 15th of June to 15th of July, 2018) in the collection sites of Limonium santapolense (Clot) and L. giradianum, L. narbonense and L. virgatum (El Saler)

\begin{tabular}{llllll}
\hline Meteorological Data & \multicolumn{2}{l}{ Clot } & & \multicolumn{2}{l}{ El Saler } \\
\cline { 2 - 3 } \cline { 5 - 6 } \cline { 5 - 6 } & June & July & & June & July \\
\hline Mean T $\left({ }^{\circ} \mathrm{C}\right)$ & 23.6 & 26.8 & & 22.7 & 26.1 \\
T max $\left({ }^{\circ} \mathrm{C}\right)$ & 32.4 & 37.4 & & 32.6 & 37.1 \\
T min $\left({ }^{\circ} \mathrm{C}\right)$ & 12.4 & 19.6 & & 12.7 & 27.8 \\
Mean H $(\%)$ & 61.9 & 64.8 & & 65.4 & 69.7 \\
H max $(\%)$ & 96.4 & 95.2 & & 95.2 & 97.8 \\
H min $(\%)$ & 23.5 & 17.2 & & 25.0 & 17.6 \\
Pp (mm) & 9.6 & 0.0 & & 136.9 & 5.8 \\
Eto (mm) & 163.1 & 187.8 & 163.0 & 184.6 \\
\hline
\end{tabular}

$T$, temperature; $H$, atmospheric humidity; $P p$, Precipitation; Eto, Evapotranspiration. Data were obtained from the nearest meteorological stations (Elche for 'Clot de Galvany' and Benifaió for El Saler)

soils in El Saler area contain a high percentage of sand, between $88 \%$ and $94 \%$, belonging therefore to the 'sandy' textural class. The texture is sandy loam at the collection site of $L$. santapolense (Clot de Galvany), as the percentage of sand in the soil is lower $(55 \%)$, and the percentage of silt is higher $(35 \%)$, whereas differences in $\%$ of clay are small in respect to the other areas.

All analysed soils had a basic $\mathrm{pH}$, with values ranging from 8.25 to 9.05 , being slightly higher in the growth area of L. girardianum and lower for that of L. santapolense. Organic matter content commonly ranges between $\leq 0.5$ and $2.0 \%$, for surface soils from arid regions (Bresler et al. 1982). Very low and similar values have been determined in the soils of Clot and $\mathrm{El}$ Saler, except in the growing area of L. narbonense, where the soil is not so poor in organic matter, although it is still below $2 \%$ (Table 3 ).

Statistically significant differences have been found in the carbonate content of the soils from Clot, where L. santapolense grows, and those of El Saler, the area where the remaining species were sampled. According to the scale of Yáñez (1989), the soils of El Saler area should be classified as soils with a high carbonate content, whereas that of Clot as soil with a very high carbonate content.

The results obtained for the cation exchange capacity (CEC) indicate similar values for L. santapolense,
L. girardianum and L. virgatum, but a higher mean value for soil samples from the area of $L$. narbonense.

Sodium and chloride concentrations in the saturation extract of all tested soils were much higher than those of the other ions measured, $\mathrm{K}^{+}, \mathrm{Ca}^{2+}$ and $\mathrm{Mg}^{2+}$. Significantly higher levels of sodium were found in the sampling areas of L. virgatum and L. narbonense, as compared to that of $L$. santapolense, with intermediate values measured for the $L$. girardianum location, whereas chlorides contents were similar in all soil samples. Magnesium was the next chemical in concentration, with higher values in the areas of the species sampled from El Saler, significantly higher than in Clot, especially in the collection zone of $L$. narbonense. Higher values in El Saler than in Clot were also registered for potassium. Finally, calcium values were significantly lower in the area of L. girardianum than in the sampling areas of the other three species.

Morphology of plants growing in the wild

Limonium virgatum and L. girardianum were small (less than $10 \mathrm{~g}$ per plant), with small leaves and thin shallow underground structures. Plants of these two species were similar, except for the higher number of shoots and leaves and longer roots of $L$. virgatum, and the higher specific length of $L$. girardianum. According to the topological measurements, both had a herringbone development in which the primary root predominates among others, and penetrates deeply in the soil without extensive branching (Magalhães and Seifert 2015) (Table 4). L. santapolense and L. narbonense both had an average biomass above $75 \mathrm{~g}$ but showed very different morphology (Table 4, Fig. 1). L. santapolense had an average of five shoots per plant and showed a larger leaf area in comparison with the other three selected species. It also showed a long underground system (averaging $187 \mathrm{~cm}$ ) that penetrated deep in the soil, reaching the proximity of the soil water table, as observed in the field.

However, it must be noticed that differences were found between $L$. santapolense plants growing in areas with a shallow water table and those growing in other areas, within the same saltmarsh but with deeper groundwater. In the first case, the plants had a short taproot with nodes evenly distributed over it (Fig. 1a, right), whereas the plants present in the second type of location develop a very long taproot (more than $1 \mathrm{~m}$ ), which only ramified when the root reaches deep moist 
Table 3 Soil variables at the collection sites of the four analysed Limonium species. Values shown are means \pm SD $(n=3)$; different lower case letters in each row indicate statistically significant differences between the different locations, according to Tukey test $(\alpha=0.05)$

\begin{tabular}{|c|c|c|c|c|}
\hline Soil variable & $\begin{array}{l}\text { L santapolense } \\
\text { Clot de Galvany }\end{array}$ & $\begin{array}{l}\text { L virgatum } \\
\text { El Saler }\end{array}$ & $\begin{array}{l}\text { L girardianum } \\
\text { El Saler }\end{array}$ & $\begin{array}{l}\text { L. narbonense } \\
\text { El Saler }\end{array}$ \\
\hline Texture & Sandy loam (55 S, $35 \mathrm{Sl}, 10 \mathrm{C})$ & Sandy (94 S, 2 Sl, 4C) & Loamy-sandy (88 S, $6 \mathrm{Sl}, 8 \mathrm{C}$ ) & Sandy (92 S, 2 Sl, 6 C) \\
\hline $\mathrm{pH}$ & $8.2 \pm 0.0 \mathrm{a}$ & $8.7 \pm 0.1 \mathrm{~b}$ & $9.1 \pm 0.0 \mathrm{c}$ & $8.5 \pm 0.1 \mathrm{~d}$ \\
\hline $\mathrm{OM}(\%)$ & $0.5 \pm 0.0 \mathrm{a}$ & $0.4 \pm 0.0 \mathrm{a}$ & $0.3 \pm 0.0 \mathrm{a}$ & $1.7 \pm 0.2 \mathrm{~b}$ \\
\hline $\mathrm{CaCO}_{3}(\%)$ & $42.3 \pm 3.6 \mathrm{~b}$ & $26.3 \pm 0.3 \mathrm{a}$ & $24.3 \pm 0.8 \mathrm{a}$ & $22.0 \pm 0.9 \mathrm{a}$ \\
\hline $\mathrm{EC}_{\text {sat }}(\mathrm{dS} / \mathrm{m})$ & $31.4 \pm 2.7 \mathrm{a}$ & $53.1 \pm 1.0 \mathrm{~b}$ & $33.9 \pm 4.4 \mathrm{a}$ & $50.3 \pm 9.3 \mathrm{~b}$ \\
\hline $\mathrm{CEC}(\mathrm{cmol}+\mathrm{kg})$ & $2.9 \pm 0.9 \mathrm{~b}$ & $1.4 \pm 0.06 \mathrm{ab}$ & $0.9 \pm 0.2 \mathrm{a}$ & $8.8 \pm 0.7 \mathrm{c}$ \\
\hline $\mathrm{Na}^{+}{ }_{\text {sat }}(\mathrm{meq} / \mathrm{L}) \mathrm{t}$ & $183.7 \pm 17.0 \mathrm{a}$ & $321.2 \pm 1.0 \mathrm{~b}$ & $239.1 \pm 33.3 \mathrm{ab}$ & $291.5 \pm 54.1 \mathrm{~b}$ \\
\hline $\mathrm{Cl}_{\text {sat }}^{-}(\mathrm{meq} / \mathrm{L})$ & $352.6 \pm 39.6 \mathrm{a}$ & $339.9 \pm 22.8 \mathrm{a}$ & $327.2 \pm 45.3 \mathrm{a}$ & $361.7 \pm 116.8 \mathrm{a}$ \\
\hline $\mathrm{K}^{+}{ }_{\text {sat }}(\mathrm{meq} / \mathrm{L})$ & $3.6 \pm 0.3 \mathrm{a}$ & $10.0 \pm 1.2 \mathrm{~b}$ & $10.2 \pm 1.8 \mathrm{~b}$ & $10.4 \pm 2.4 \mathrm{~b}$ \\
\hline $\mathrm{Ca}^{2+}$ sat $(\mathrm{meq} / \mathrm{L})$ & $17.1 \pm 2.4 \mathrm{~b}$ & $14.9 \pm 4.3 b$ & $6.0 \pm 0.8 \mathrm{a}$ & $15.7 \pm 1.7 b$ \\
\hline $\mathrm{Mg}^{2+}$ sat $(\mathrm{meq} / \mathrm{L})$ & $16.6 \pm 1.5 \mathrm{a}$ & $23.6 \pm 0.1 \mathrm{~b}$ & $30.7 \pm 0.3 \mathrm{c}$ & $37.9 \pm 4.3 \mathrm{~d}$ \\
\hline
\end{tabular}

$S, \%$ sand; $S l, \%$ silt; $C$, \% clay; $O M$, organic matter; ECsat, electric conductivity in saturation extract

areas in the soil (Fig. 1a, left). Regarding the topological indexes, it was a moderate herringbone root even though, as we have pointed out above, it can grow very deep as a single root (Fig. 1a). In terms of underground systems, L. narbonense was very different from the rest due to its rhizomatous root system. It has a rhizomatous structure of 2-3 cm in diameter, which penetrates the soil up to $40 \mathrm{~cm}$ and then starts to branch. This structure was covered by fine roots of 1-2 $\mathrm{mm}$ in diameter and up to $10 \mathrm{~cm}$ in length. The topological index of L. narbonense corroborates its herringbone structure (Fig. 1b).

Table 4 Means and standard deviations of shoot and root traits evaluated from wild plants of the four Limonium species $(n=4)$

\begin{tabular}{lllll}
\hline Traits & L. santapolense & L. virgatum & L. girardianum & L. narbonense \\
\hline NS & $5.0 \pm 0.7 \mathrm{~b}$ & $11.5 \pm 1.8 \mathrm{c}$ & $1.0 \pm 0.0 \mathrm{a}$ & $2.8 \pm 0.7 \mathrm{ab}$ \\
NL & $43.8 \pm 7.5 \mathrm{bc}$ & $63.3 \pm 8.3 \mathrm{c}$ & $23.8 \pm 3.7 \mathrm{ab}$ & $15.2 \pm 8.6 \mathrm{a}$ \\
SFW $(\mathrm{g})$ & $70.0 \pm 21.4 \mathrm{a}$ & $6.6 \pm 0.8 \mathrm{a}$ & $2.0 \pm 0.30 \mathrm{a}$ & $47.3 \pm 22.4 \mathrm{a}$ \\
RFW $(\mathrm{g})$ & $5.2 \pm 0.7 \mathrm{a}$ & $1.0 \pm 0.2 \mathrm{a}$ & $0.2 \pm 0.1 \mathrm{a}$ & $50.2 \pm 18.1 \mathrm{~b}$ \\
LA $\left(\mathrm{cm}^{2}\right)$ & $552.3 \pm 150.3 \mathrm{~b}$ & $33.6 \pm 5.6 \mathrm{a}$ & $23.9 \pm 4.7 \mathrm{a}$ & $98.2 \pm 47.4 \mathrm{a}$ \\
RL $\left(\mathrm{cm}^{2}\right)$ & $187.4 \pm 49.2 \mathrm{a}$ & $120.4 \pm 43.2 \mathrm{a}$ & $57.4 \pm 14.6 \mathrm{a}$ & $83.7 \pm 28.4 \mathrm{a}$ \\
LRL $(\mathrm{cm})$ & $152.1 \pm 55.7 \mathrm{a}$ & $113.7 \pm 42.7 \mathrm{a}$ & $54.7 \pm 13.7 \mathrm{a}$ & $45.0 \pm 21.9 \mathrm{a}$ \\
PRL $(\mathrm{cm})$ & $35.3 \pm 10.6 \mathrm{~b}$ & $6.5 \pm 1.1 \mathrm{a}$ & $2.6 \pm 1.2 \mathrm{a}$ & $38.7 \pm 10.5 \mathrm{~b}$ \\
RSA $\left.(\mathrm{cm})^{2}\right)$ & $85.0 \pm 14.3 \mathrm{ab}$ & $35.1 \pm 10.9 \mathrm{a}$ & $15.6 \pm 4.1 \mathrm{a}$ & $162.5 \pm 49.1 \mathrm{~b}$ \\
D $(\mathrm{mm})$ & $1.6 \pm 0.3 \mathrm{a}$ & $1.0 \pm 0.0 \mathrm{a}$ & $0.9 \pm 0.1 \mathrm{a}$ & $6.9 \pm 1.2 \mathrm{~b}$ \\
R/S & $0.1 \pm 0.0 \mathrm{a}$ & $0.1 \pm 0.0 \mathrm{a}$ & $0.1 \pm 0.0 \mathrm{a}$ & $2.2 \pm 1.4 \mathrm{a}$ \\
SRL $(\mathrm{cm} / \mathrm{g})$ & $37.9 \pm 9.6 \mathrm{a}$ & $113.5 \pm 19.5 \mathrm{ab}$ & $273.9 \pm 68.3 \mathrm{~b}$ & $2.0 \pm 0.5 \mathrm{a}$ \\
M & $27.7 \pm 11.6 \mathrm{ab}$ & $56.7 \pm 8.7 \mathrm{c}$ & $40.7 \pm 10.4 \mathrm{bc}$ & $5.5 \pm 1.2 \mathrm{a}$ \\
A & $9.7 \pm 2.9 \mathrm{ab}$ & $22.2 \pm 4.8 \mathrm{c}$ & $20.7 \pm 5.7 \mathrm{bc}$ & $5.2 \pm 0.6 \mathrm{a}$ \\
Nd & $21.0 \pm 8.1 \mathrm{ab}$ & $53.0 \pm 9.8 \mathrm{c}$ & $0.8 \pm 0.0 \mathrm{a}$ & $4.5 \pm 0.9 \mathrm{a}$ \\
TI & $0.7 \pm 0.1 \mathrm{a}$ & $0.8 \pm 0.1 \mathrm{a}$ & $1.0 \pm 0.1 \mathrm{~b}$ \\
\hline
\end{tabular}

$N S$, number of apical shoots; $N L$, number of leaves, $S F W$, shoot fresh weight $(\mathrm{g}) ; R F W$, root fresh weight $(\mathrm{g}) ; L A$, total leaf area (cm $\left.{ }^{2}\right) ; R L$, total root length $(\mathrm{cm}) ; L R L$, lateral root length $(\mathrm{cm}) ; P R L$, taproot or principal root length $(\mathrm{cm}) ; R S A$, root surface area $\left(\mathrm{cm}^{2}\right) ; D$, average diameter of the roots $(\mathrm{mm}) ; R / S$, root to shoot ratio; $S R L$, specific root length $(\mathrm{cm} / \mathrm{g}) ; M$, root magnitude; $a$, root altitude; $N d$, numbers of root nodes; $T I$, topological index. Numbers of the same row followed by different letter differ significantly in the ANOVA test at $P<0.05$ 

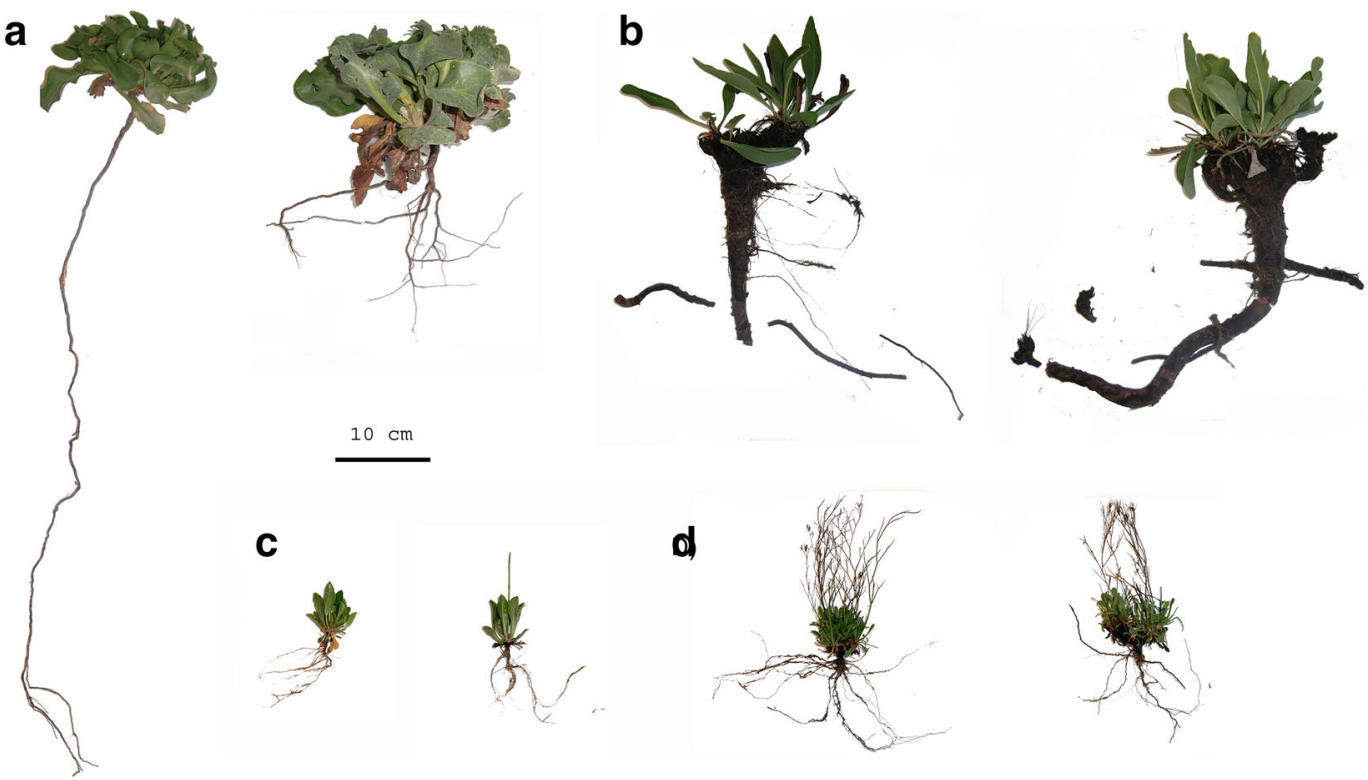

Fig. 1 Examples of the four Limonium species sampled in the wild: L. santapolense (a), L. narbonense (b), L. girardianum (c) and L. virgatum (d)

Ion accumulation

Levels of ions and their interspecific variation were generally higher in leaves than in roots, and these differences were, in most cases, statistically significant (Fig. 2). Mean $\mathrm{Na}^{+}$concentrations were higher in $L$. girardianum and $L$. narbonense than in $L$. santapolense and $L$. virgatum, ranging in leaves from $631 \mu \mathrm{mol} \mathrm{g}{ }^{-1} \mathrm{DW}$ in L. santapolense to $1993 \mu \mathrm{mol} \mathrm{g}$ DW in L. narbonense, but the differences were significant only in roots, due to the wide individual variation within each species in the leaves (Fig. 2a). $\mathrm{Cl}^{-}$concentrations in roots were significantly lower than in leaves in all four species and did not vary between species, whereas in leaves significantly higher $\mathrm{Cl}^{-}$levels of $467 \mu \mathrm{mol} \mathrm{g}^{-1} \mathrm{DW}$ were found in L. narbonense, as compared to around $200 \mu \mathrm{mol} \mathrm{g}-1$ DW in leaves of the other three taxa (Fig. 2b). Also, root $\mathrm{K}^{+}$concentrations did not differ in the four species, whereas $\mathrm{K}^{+}$concentrations in leaves were significantly higher in L. santapolense and L. virgatum than in L. girardianum, whereas L. narbonense showed intermediate values (Fig. 2c). The most considerable differences between root and leaf $\mathrm{Ca}^{2+}$ concentrations were observed in L. santapolense, which showed very low levels of this cation in the roots but stood out by its high levels of foliar $\mathrm{Ca}^{2+}$ concentrations, up to $319 \mu \mathrm{mol} \mathrm{g}$
DW, much higher than those measured in the other three species (Fig. 2d).

\section{Osmolyes}

The most common osmolytes in halophytes, proline (Pro), glycine betaine (GB) and total soluble sugars (TSS) were quantified in plant leaves of the four Limonium species (Table 5). Levels of Pro in L. santapolense and $L$. virgatum were lower - below $20 \mu \mathrm{mol} \mathrm{g}{ }^{-1} \mathrm{DW}$ - than those measured in L. giradianum and L. narbonense - ca. 50 and $75 \mu \mathrm{mol}$ $\mathrm{g}^{-1} \mathrm{DW}$, respectively. Regarding leaf GB concentrations, L. santapolense showed the lowest value, about $14 \mu \mathrm{mol}$ $\mathrm{g}^{-1} \mathrm{DW}$, whereas similar concentrations, ca. $40 \mu \mathrm{mol} \mathrm{g}{ }^{-1}$ DW, were measured in the other three species. TSS ranged from the lowest value (around $40 \mathrm{mg}$ eq. glucose $\left.\mathrm{g}^{-1} \mathrm{DW}\right)$ in L. virgatum to the highest $(\sim 70 \mathrm{mg}$ eq. glucose $\mathrm{g}^{-1} \mathrm{DW}$ ) in L. santapolense (Table 5).

In addition to the spectrophotometric determination of TSS, individual sugars in the leaf watersoluble fraction were separated, identified and quantified by HPLC. Three peaks were detected in the chromatograms, corresponding to fructose (Fru), sucrose (Suc), and glucose (Glu). Fru concentrations were very low in L. santapolense $\left(25.5 \mu \mathrm{mol} \mathrm{g}{ }^{-1}\right.$ DW) in comparison with the other taxa $(656 \mu \mathrm{mol}$ 

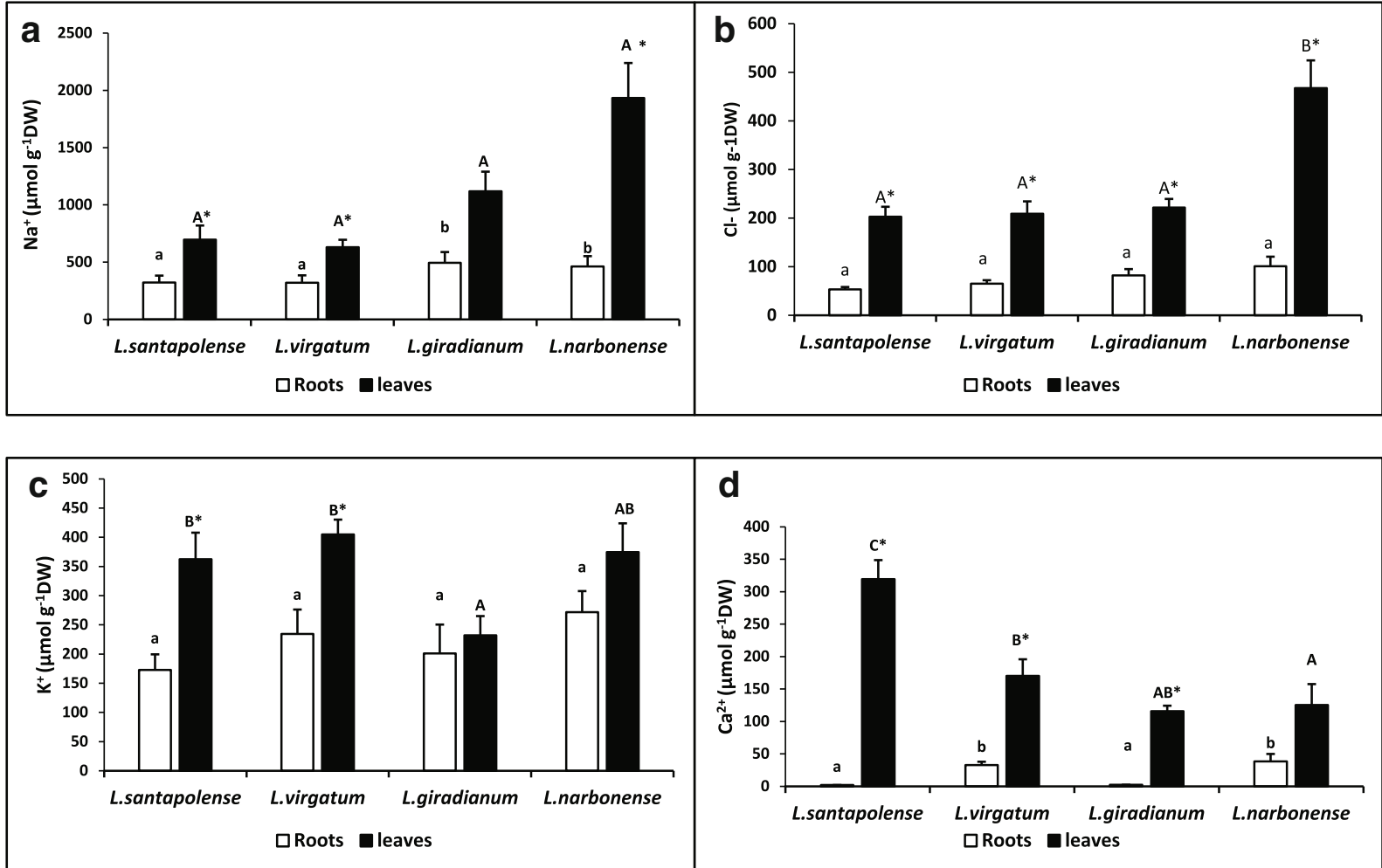

Fig. 2 Ions levels in roots and leaves of the four Limonium species sampled in the field. $\mathrm{Na}^{+}(\mathbf{a}) ; \mathrm{Cl}^{-}(\mathbf{b}) ; \mathrm{K}^{+}(\mathbf{c}) ; \mathrm{Ca}^{2+}(\mathbf{d})$. Bars represent means $\pm \mathrm{SD}(n=4)$. Asterisks indicate significant

$\mathrm{g}^{-1} \mathrm{DW}$ in L. giradianum, for example), whereas the reverse pattern was observed in the case of Suc, which showed very low levels in all species (bellow 1 in L. girardainum and L. narbonense) except in differences between roots and leaves for each species, and letters significant differences between species (lower-case letters for roots and capital letters for leaves) at $P<0.05$

L. santapolense $\left(75.5 \mu \mathrm{mol} \mathrm{g}{ }^{-1} \mathrm{DW}\right)$. Finally, Glu levels were also low in all species, somewhat higher

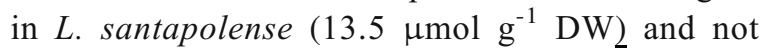
detectable in L. girardianum (Table 5).

Table 5 Biochemical parameters quantified in the leaves of plants sampled in the wild of four Limonium species. Mean followed by SE, $n=$ 4

\begin{tabular}{|c|c|c|c|c|}
\hline Biochemical Parameters & L. santapolense & L. virgatum & L. giradianum & L. narbonense \\
\hline Pro $\left(\mu \mathrm{mol} \mathrm{g} \mathrm{g}^{-1} \mathrm{DW}\right)$ & $19.3 \pm 1.8 \mathrm{a}$ & $14.7 \pm 0.4 \mathrm{a}$ & $47.7 \pm 2.2 \mathrm{~b}$ & $75.6 \pm 25.5 \mathrm{c}$ \\
\hline $\mathrm{GB}\left(\mu \mathrm{mol} \mathrm{g}{ }^{-1} \mathrm{DW}\right)$ & $14.2 \pm 1.3 \mathrm{a}$ & $42.6 \pm 6.8 b$ & $40.3 \pm 3.2 b$ & $42.0 \pm 3.2 \mathrm{~b}$ \\
\hline TSS (mg eq. $\mathrm{G} \mathrm{g}^{-1} \mathrm{DW}$ ) & $70.2 \pm 5.2 \mathrm{c}$ & $38.7 \pm 2.7 \mathrm{a}$ & $67.0 \pm 0.7 \mathrm{c}$ & $54.7 \pm 4.8 b$ \\
\hline Fru $\left(\mu \mathrm{mol} \mathrm{g}{ }^{-1} \mathrm{DW}\right)$ & $27.6 \pm 2.1 \mathrm{a}$ & $632.0 \pm 22.1 \mathrm{c}$ & $656.5 \pm 244.2 \mathrm{~d}$ & $291.0 \pm 91.6 b$ \\
\hline Suc $\left(\mu \mathrm{mol} \mathrm{g}{ }^{-1} \mathrm{DW}\right)$ & $73.5 \pm 14.6 \mathrm{~b}$ & $9.0 \pm 1.4 \mathrm{a}$ & $0.7 \pm 0.1 \mathrm{a}$ & $0.3 \pm 0.0 \mathrm{a}$ \\
\hline Glu ( $\left.\mu \mathrm{mol} \mathrm{g}{ }^{-1} \mathrm{DW}\right)$ & $13.6 \pm 0.2 \mathrm{c}$ & $8.2 \pm 2.2 b$ & $0.0 \mathrm{a}$ & $6.5 \pm 0.4 \mathrm{~b}$ \\
\hline $\operatorname{MDA}\left(\mathrm{nmol} \mathrm{g}^{-1} \mathrm{DW}\right)$ & $171.4 \pm 5.3 \mathrm{~b}$ & $97.4 \pm 8.7 \mathrm{a}$ & $210.3 \pm 25.4 b$ & $191.6 \pm 35.5 b$ \\
\hline DPPH $(\%)$ & $84.2 \pm 0.3 b$ & $67.6 \pm 7.3 \mathrm{a}$ & $82.8 \pm 1.1 \mathrm{~b}$ & $74.5 \pm 4.0 \mathrm{ab}$ \\
\hline TPC (mg eq. GA g ${ }^{-1} \mathrm{DW}$ ) & $37.1 \pm 3.7 \mathrm{a}$ & $23.9 \pm 6.2 \mathrm{a}$ & $39.2 \pm 4.8 \mathrm{a}$ & $24.9 \pm 5.2 \mathrm{a}$ \\
\hline $\mathrm{TF}\left(\mathrm{mg}\right.$ eq. $\left.\mathrm{C} \mathrm{g}^{-1} \mathrm{DW}\right)$ & $5.9 \pm 0.3 \mathrm{~b}$ & $6.9 \pm 0.5 \mathrm{~b}$ & $4.0 \pm 0.4 \mathrm{a}$ & $2.9 \pm 0.6 \mathrm{a}$ \\
\hline
\end{tabular}

Pro, proline; GB, glycine betaine; TSS, total soluble sugars; Fru, fructose; Suc, sucrose; Glu, glucose; $M D A$, malondialdehyde; $D P P H, 2,2-$ diphenyl-1-picrylhydrazyl; $T P C$, total phenolic compounds; $T F$, total flavonoids 
Oxidative stress and antioxidant compounds

Malondialdehyde (MDA) is a product of peroxidation of unsaturated fatty acids, used as a reliable marker of free radical damage to cell membranes in plants and animals (Del Rio et al. 2005; Suzuki and Mittler 2006). The DPPH-free radical scavenging assay is a useful method for quantifying the ability of compounds in an extract to act as free radical scavengers or hydrogen donors, indicating the overall antioxidant capacity of the sample (Sagar et al. 2011). Both biochemical markers were determined in plants of the four Limonium taxa. No significant differences were found between L. santapolense, L. girardianum and L. narbonense, and somewhat lower values were measured in L. virgatum (Table 5), indicating that the degree of oxidative stress affecting the plants in the field and the total antioxidant activity of the leaf extracts were roughly the same in all cases.

In response to oxidative stress, plants activate enzymatic and non-enzymatic antioxidant mechanisms. Synthesis of phenolic compounds, including flavonoids, many of them possessing strong antioxidant activities, is one of the most frequent and most efficient strategies used by plants to reduce oxidative stress. Total phenolic compounds (TPC) were measured in leaves of plants of the four Limonium species, and ranged from $23.9 \mathrm{mg}$ eq. $\mathrm{GA} \mathrm{g}^{-1} \mathrm{DW}$ in L. virgatum to 39.2 in L. giradianum with no significant interspecific differences observed. Flavonoid concentrations were significantly lower in L. girardianum (4.0 $\mathrm{mg}$ eq. $\mathrm{C}^{-1} \mathrm{DW}$ ) and L. narbonense (2.9) than in L. santapolense (5.9) and L. virgatum (6.9) but these differences are probably irrelevant in terms of antioxidant capacity since absolute TF values were very low in all cases (Table 5).

PCA and cluster analysis

A Pearson Moment Correlation was performed with all analysed parameters and those plant and soil variables that showed a significant correlation were further subjected to a Principal Component Analysis (PCA) (Table 6 and Fig.3). Climatic data could not be included since three of the species analysed, L. virgatum, $L$. girardianaum and $L$. narbonense were sampled from the same area, so plants grew in the same climatic conditions. The PCA extracted four components with an eigenvalue higher than one out of the total 25 parameters considered. Together, the four components account for $88.6 \%$ of the total variability. The first component, explaining $45.2 \%$ of the variability, was mostly related to soil parameters (positively with $\mathrm{EC}, \mathrm{K}^{+}, \mathrm{Mg}^{2+}$ and $\mathrm{Na}^{+}$levels in the soil, and negatively with the percentage of $\mathrm{CaCO}_{3}$ ), and also correlated with osmolytes, positively with glycine betaine (GB) and negatively with sucrose (Suc). The second component, which explained an additional $23.8 \%$ of the total variability, was positively related to the levels of $\mathrm{Ca}$ in soil and with glucose (Glu), and negatively related to the concentrations of the oxidative stress marker (MDA), total antioxidant activity (DPPH), total phenolics (TPC) and total soluble sugars (TSS) in the plants (Table 6).

The loading plot indicates that the concentrations of $\mathrm{Na}^{+}$and $\mathrm{Cl}^{-}$in the soil correlated positively with those in the leaves of plants, and with the osmolytes Pro, GB and Fru. Growth parameters [fresh weight of shoots (SFW), leaf area (LA) and length of the roots (LR)] are grouped together (Fig.3). The projection of the four individuals of the four species in the PCA score plot shows a clear separation along the first component of L. santapolense, due to the particularity of its habitat with higher soil level of $\mathrm{CaCO}_{3}$ (Fig.3); this taxon is also separated from the other species based on its high levels of foliar sucrose (Suc) and low values of fructose (Fru). L. narbonense and L. virgatum were situated on the opposite side, as they grow in soils with higher concentrations of $\mathrm{Na}^{+}, \mathrm{K}^{+}$and $\mathrm{Mg}^{2+}$, and therefore higher EC. Limonium girardianum was separated along the second component due to its higher values of MDA.

A cluster analysis based on the nearest neighbour method, including only morphological traits, biochemical parameters and ion concentrations of the plants, also separated the four species and supported the results of the PCA (Fig. 4). The more distant species was again L. santapolense, and the most related, based on the analysed characteristics, were L. narbonense and L. girardianum.

\section{Discussion}

In previous studies performed in our laboratory, it was found that once the bottleneck of germination was overcome, the four studied Limonium species tolerated high salinity levels, up to $800 \mathrm{mM} \mathrm{NaCl}$ in the irrigation solution (Al Hassan et al. 2017), but they differed in their responses to water deficit. Plants of three taxa, L. virgatum, L. girardianum and L. narbonense, grown 
Table 6 Weights of the main four principal components extracted by the PCA in the four Limonium species

\begin{tabular}{|c|c|c|c|c|}
\hline Component & Component 1 & Component 2 & Component 3 & Component 4 \\
\hline Eigenvalue & 11.30 & 5.96 & 3.75 & 1.13 \\
\hline Variance $(\%)$ & 45.20 & 23.86 & 15.00 & 4.53 \\
\hline $\mathrm{pH}$ & 0.16 & -0.29 & -0.18 & -0.09 \\
\hline $\mathrm{EC}$ & 0.23 & 0.24 & -0.00 & 0.11 \\
\hline $\mathrm{CaCO}_{3}$ & -0.28 & 0.07 & -0.06 & 0.14 \\
\hline $\mathrm{OM}$ & 0.09 & 0.17 & 0.38 & -0.17 \\
\hline $\mathrm{Na}^{+} \mathrm{s}$ & 0.27 & 0.14 & -0.06 & 0.084 \\
\hline $\mathrm{K}^{+} \mathrm{s}$ & 0.28 & -0.07 & 0.01 & -0.11 \\
\hline $\mathrm{Mg}^{2+} \mathrm{s}$ & 0.25 & 0.16 & 0.12 & -0.02 \\
\hline $\mathrm{Ca}^{2+} \mathrm{S}$ & -0.08 & 0.37 & 0.10 & 0.18 \\
\hline $\mathrm{Cl}^{-} \mathrm{s}$ & 0.19 & 0.27 & -0.08 & 0.19 \\
\hline $\mathrm{Na}^{+} 1$ & 0.08 & 0.05 & 0.45 & 0.08 \\
\hline $\mathrm{Cl}^{-1}$ & 0.13 & 0.13 & 0.29 & -0.07 \\
\hline $\mathrm{Ca}^{2+} 1$ & -0.19 & 0.07 & -0.14 & 0.33 \\
\hline $\mathrm{Ca}^{2+} \mathrm{r}$ & 0.21 & 0.25 & -0.01 & 0.18 \\
\hline MDA & -0.03 & -0.24 & 0.36 & 0.11 \\
\hline GB & 0.25 & -0.08 & 0.01 & 0.16 \\
\hline TSS & -0.18 & -0.21 & 0.22 & -0.05 \\
\hline TPC & -0.11 & -0.26 & 0.12 & 0.44 \\
\hline Pro & 0.10 & -0.10 & 0.41 & 0.05 \\
\hline DPPH & -0.14 & -0.22 & 0.192 & 0.22 \\
\hline Fru & 0.20 & -0.23 & -0.16 & -0.07 \\
\hline Glu & -0.18 & 0.30 & -0.00 & 0.17 \\
\hline Suc & -0.27 & 0.09 & -0.02 & 0.20 \\
\hline LA & -0.24 & 0.12 & 0.062 & -0.29 \\
\hline RL & -0.19 & 0.14 & 0.01 & -0.29 \\
\hline SFW & -0.21 & 0.15 & 0.12 & -0.35 \\
\hline
\end{tabular}

$E C$, soil electric conductivity; $\mathrm{CaCO}_{3}$, calcium carbonate in soil; $\mathrm{OM}$, soil organic matter; $\mathrm{Na}^{+} s$, sodium in soil; $\mathrm{K}^{+} s$, potassium in soil; $\mathrm{Mg}^{2+} \mathrm{s}$, magnesium in soil; $\mathrm{Ca}^{2+} \mathrm{s}$, calcium in soil; $\mathrm{Cl} s$, chloride in soil; $\mathrm{Na}^{+} l$, sodium in leaves; $\mathrm{Cl} l$, chloride in leaves; $\mathrm{Ca}^{2+} l$, calcium in leaves; $\mathrm{Ca}^{2+} r$, calcium in roots; $M D A$, malondialdehyde; $G B$, glycine betaine; $T S S$, total soluble sugars; $T P C$, total phenolic compounds; Pro, proline; DPPH, 2,2-diphenyl-1-picrylhydrazyl; Fru, fructose; Glu, glucose; Suc, sucrose; $L A$, total leaf area; $R L$, total root length; $S F W$, shoot fresh weight

in pots did not show a drastic reduction of growth after one month of lack of irrigation, whereas those of L. santapolense lost one-third of its fresh weight (González-Orenga et al. 2019).

Climate analysis of the sampling zones of L. santapolense at Clot de Galvany and the other three species at El Saler revealed differences between the two areas in the amount of rainfall, which lead to different climate types: arid for the first and semi-arid for the second. Although dry summers represent a characteristic trait of the Mediterranean climate, during the month previous to sampling the water deficit was much more pronounced in the area of $L$. santapolense at Clot than in El Saler, where in the last two weeks of June the rainfall was over $130 \mathrm{~mm}$. Soil analyses did not reveal big differences between the sampling sites, except the texture of the soil, which was sandy-loam for the L. santapolense's collection area and sandy in the other three sites. This difference is related to the geology of the two zones. The Clot area belongs to the undifferentiated quaternary and combines a series of more recent formations such as colluvia, alluvium, brackish deposits and debris in general (IGME 1973) that increased the levels of carbonates, whereas the salt marshes in El Saler 


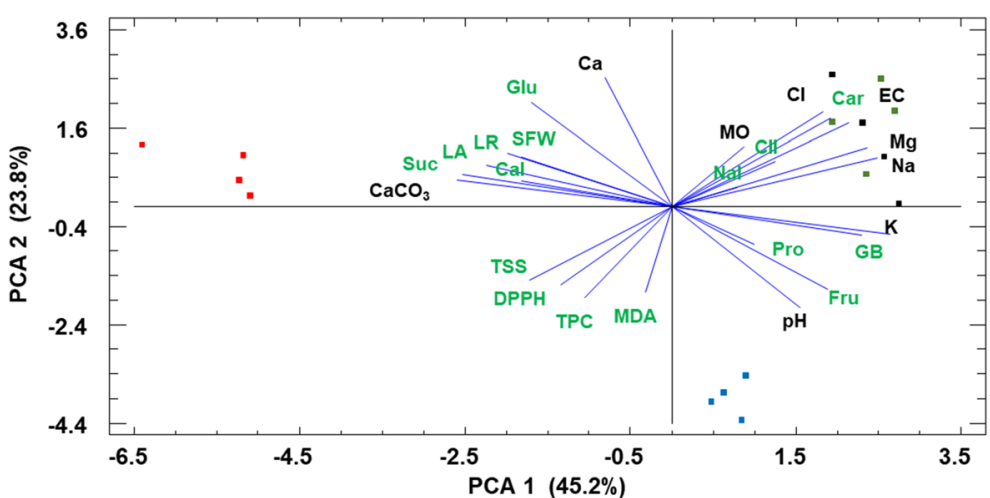

Fig. 3 Diagram showing the relationships among the plants' traits (3 morphological, 13 biochemical) with nine soil parameters measured in their collection sites and among the 16 individuals from the four species of Limonium: L. santapolense (red), L. narbonense (black), L. girardianum (blue) and L. virgatum (green) based on the two first principal components of a principal components analysis (PCA). Soil parameters in black and plant parameters in green. Abbreviations: EC, soil electric conductivity; $\mathrm{CaCO}_{3}$, calcium carbonate in soil; OM, soil organic matter; $\mathrm{Na}^{+}$,

area, also of quaternary origin, were formed behind the dunar belt, with deposits of grey sandy silts (IGME 1974). This difference in texture can be significant after rain periods, as the soil in Clot has a slightly better ability to retain moisture than the sandy soils in El Saler. Although the substrate is sandy in El Saler, with very low water-holding capacity, this area is located in the immediate proximity of the sea, which makes the sodium in soil; $\mathrm{K}^{+} \mathrm{s}$ potassium in soil; $\mathrm{Mg}^{2+} \mathrm{s}$, magnesium in soil; $\mathrm{Ca}^{2+} \mathrm{s}$, calcium in soil; $\mathrm{Cl}^{-} \mathrm{s}$ chloride in soil; $\mathrm{Na}^{+} 1$, sodium in leaves; $\mathrm{Cl}^{-} 1$, chloride in leaves; $\mathrm{Ca}^{2+}$, calcium in leaves; $\mathrm{Ca}^{2+} \mathrm{r}$, calcium in roots; MDA, malondialdehyde; GB glycine betaine; TSS, total soluble sugars; TPC, total phenolic compounds; Pro, proline; DPPH, 2,2-diphenyl-1-picrylhydrazyl; Fru, fructose; Glu, glucose; Suc, sucrose; LA, total leaf area; RL, total root length; SFW, shoot fresh weight

climate more humid and intensifies the cryptoprecipitation. Therefore, despite the differences in the texture of the soil, Clot de Galvany represents a drier habitat than El Saler. In fact, soil humidity registered by a WET 2 sensor simultaneously with plant uprooting did not show apparent differences between the areas of the four species and varied in surface $(10 \mathrm{~cm}$ depth) from 5 to $15 \%$. The cation exchange capacity
Fig. 4 Cluster analysis based on the morphological and biochemical traits measured in plants of L. santapolense (Ls), L. narbonense (Ln), L. girardianum $(\mathrm{Lg})$ and L. virgatum $(\mathrm{Lv})$

\section{Dendrogram Nearest Neighbor Method,Squared Euclidean}

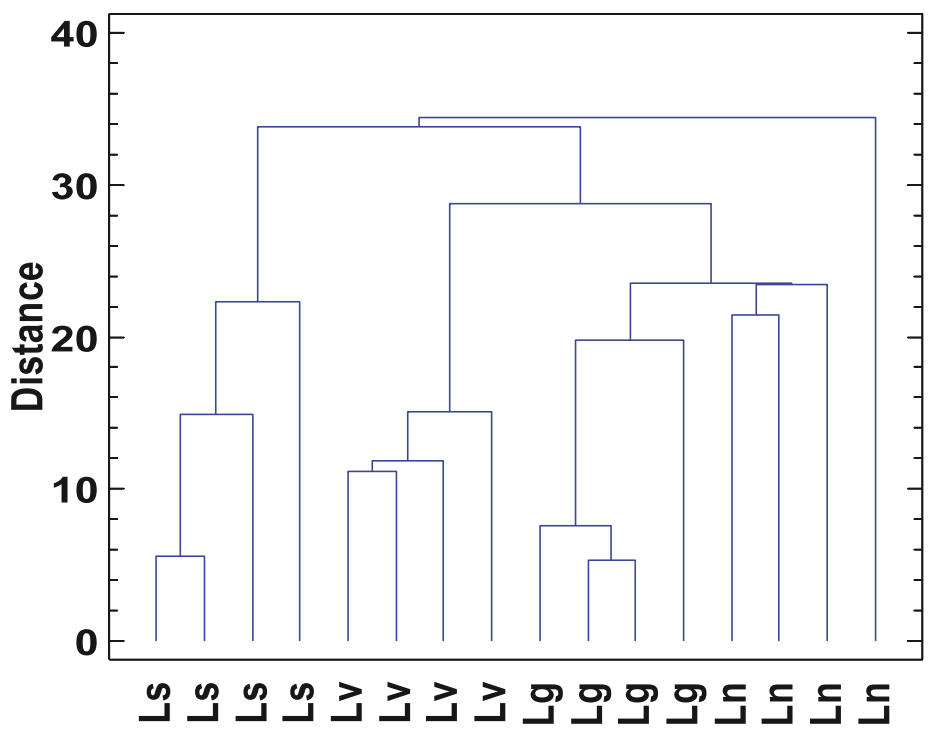


(CEC) is an essential trait of soils, influencing their stability and nutrient availability (Hazelton and Murphy 2007). CEC depends on the organic matter and clay proportion in soils. The more elevated CEC in the area of $L$. narbonense is explained by its higher content in organic matter. However, although soil from Clot had a higher proportion of clay, due to its very low $\mathrm{OM} \%, \mathrm{CEC}$ is only slightly higher in this area than in those of $L$. giradianum and $L$. virgatum.

Since studies conducted in the greenhouse (González-Orenga et al. 2019) indicated that L. santapolense is the species most sensitive to water deficit, it was clear that plants growing in their natural environments possess some specific mechanisms of defence against drought, which are not effective under artificial conditions in potted plants. The root system of plants has an essential function in their adaptation to drought, because roots serve as the interphase between plants and soil, and play a key role in plant nutrition and development. As they are directly sensing the physicochemical parameters of the soil, roots are essential in the adaptation of plants to different environments (Franco et al. 2011; Fry et al. 2018). According to databases such as PLANTATT, there are several main categories of roots, such as tap-rooted, rhizomatous, stoloniferous or fibrous (Hill et al. 2004. Three of the Limonium species analysed in the present work (L. santapolense, L. girardianum and L. virgatum) have a simple morphology consisting of a central primary underground system with few lateral roots and a low surface area to volume ratio. This type of roots are poor foragers for resources in shallow soils and are not optimal for microbial symbiosis (Fry et al. 2018, and references therein), but can reach deep soil layers (Alvarez-Flores et al. 2018). Some tap-rooted species in arid and semiarid areas have the ability to produce a hydraulic lift (an upwards transport of water from the deeper, moister layers of soil to the shallow, drier zone), and act as 'nurse plants', beneficial for other plant species by redistributing water from deeper soil layers (Prieto et al. 2011). The fourth species under study, $L$. narbonense, presented a rhizomatous root as described in other Limonium species (Eber and Veenhuis 1991; Antonelli-Ushirobira et al. 2015). Such structures are adapted for storing high amounts of carbohydrates and nitrogenous reserves (Suzuki and Stuefer 1999; Schmidt and Gaudin 2017).

Although the main morphological types are stable within species, underground system development shows high plasticity in relation to different types of abiotic stresses. Substantial variations in their length, branching and other morphologic and structural aspects may appear even within the same species when environmental conditions are different (Franco et al. 2011, and references therein). In the case of L. santapolense, collected from the arid area at Clot de Galvany, a substantial variation in root length was noticed. Plants growing in more humid soils near the waterlogged depressed part of the salt marsh had short taproot with nodes evenly distributed over it, whereas the plants growing distantly from the water develop a very long taproot and the main root is branched only in deeper, more humid layers of the soil. In the case of the species sampled from El Saler, roots did not show such a strong morphological variation. The development of long roots able to explore deeper moist layers of the soil may explain the fact that L. santapolense grows in arid areas, although under controlled conditions was the species most affected by water stress. When growing in a standard pot of $9 \mathrm{~cm}$ diameter, plants of this species were affected after one month of imposed water stress while in the wild they tolerate much longer periods of drought, sometimes extending to more than three months without precipitations.

In addition to the root type, many ecophysiological traits may have an adaptive value, enabling plants to inhabit stressful natural environments. Limonium species are well-known recretohalophyes, plants that have the ability to secrete salts through salt glands (Leng et al. 2018), but they also accumulate salts in their leaves like many other dicotyledonous halophytes (Wyn-Jones and Gorham 2002; Flowers and Colmer 2008). By sequestration of toxic ions in their vacuoles, these plants achieve a cheap osmoticum (Flowers and Yeo 1986) and also require little $\mathrm{K}^{+}$ for cytosolic metabolism (Zia et al. 2008; Hameed et al. 2015). When examining $\mathrm{Na}^{+}$in roots and leaves, its level was higher in leaves, as it was already reported in these species (Al Hassan et al. 2017); differences between species were not significant. $\mathrm{Cl}^{-}$followed a similar pattern, accumulating considerably larger concentrations in leaves than in roots. For both ions, the most significant difference between roots and leaves was detected in L. narbonense, sampled in a strongly saline area. The active transport and sequestration in leaf vacuoles of toxic ions was reported in other Limonium 
species (Hameed et al. 2015) and may also represent a mechanism of avoidance of toxic ions at the underground level, where osmoregulation is achieved by the accumulation of free osmotic solutes (Alarcon et al. 1999). In addition to $\mathrm{Na}^{+}$and $\mathrm{Cl}^{-}$transport to the aerial part of the plants, $\mathrm{Ca}^{2+}$ accumulation in the leaves can also contribute to salt tolerance mechanisms in the analysed Limonium taxa, especially in L. santapolense, the species showing highest leaf concentrations of this cation, as the essential role of $\mathrm{Ca}^{2+}$ in alleviating the deleterious effects of salinity is well established (Hasegawa et al. 2000; Hadi and Karimi 2012).Limonium santapolense also showed a striking difference from the other three selected species, regarding the major osmolytes synthesised for osmotic balance under the stressful conditions of their natural habitats. Plants of this species showed much lower leaf concentrations of Fru and also, in general, significantly lower concentrations of Pro and GB than those of $L$. virgatum, L. giradianum and L. narbonense. Osmotic adjustment in L. santapolense seems to be achieved by the accumulation of Suc - and, to a lesser extent, Glu - which is present at much higher levels than in the other three taxa. In contrast, under experimental conditions in the greenhouse, when plants of this species were strongly affected by drought, levels of Pro, Fru and Suc were much higher than those measured in the other species (González-Orenga et al. 2019). These data, together with published reports on other Limonium species (e.g., Hanson et al. 1991; Liu and Grieve 2009), support the notion that osmolyte biosynthesis is extremely variable in this genus, in contrast to other genera that use a single compound as the primary functional osmolyte, for example, sorbitol in Plantago (Flowers and Colmer 2008).

In the present work, measurements in the four selected Limonium species of leaf concentrations of MDA which is routinely used to assess the oxidative damage induced in plants by different stress treatments (e.g. Aghaleh et al. 2009; Demiral and Türkan 2005) - did not reveal, in general, significant interspecific differences. Similarly, the total antioxidant activity of leaf extracts - determined by the DPPH-free radical scavenging assay - or the total phenolic compounds concentrations - as relevant non-enzymatic antioxidants - varied little between the four taxa, non-significantly in most cases. This indicated that $L$. santapolense plants were affected in the field roughly by the same degree of oxidative stress than plants of the other three taxa and that the antioxidant responses were also similar in all cases, despite the different aridity of the corresponding habitats.

The analysis of the responses to environmental stress of the four studied Limonium species using field-collected material complements previous work in which plants of the same species were subjected to salt stress (Al Hassan et al. 2017) or water stress (González-Orenga et al. 2019)) treatments under controlled greenhouse conditions. Although the general physiological and biochemical responses to stress may be qualitatively similar, comparisons between the two types of experiments should be taken with caution. First, in the greenhouse plants are likely affected by much higher levels of salt or water stress, as their root systems are constrained in the pots to closed and limited environments of relatively homogeneous salinity and moisture. On the contrary, plants in the wild may develop longer roots, with different morphology better adapted to a more heterogeneous environment, where salinity and soil moisture largely vary in different locations and in time, as we show here for L. santapolense. Second, the developmental stage was different between greenhouse and field, young plants grown from seeds were used in the greenhouse experiments versus adult plants of unknown age (the four species are perennial) grown in the field. Moreover, the salt and water stress treatments applied in the greenhouse cannot mimic the conditions in nature - specifically, in this case, in Mediterranean salt marshes in summer - where plants are simultaneously affected by different types and varying degrees of environmental stress, including drought, soil salinity, elevated temperatures, and UV irradiation.

\section{Conclusions}

The analysis of the biochemical responses to environmental stress of four Limonium species in littoral salt marshes in SE Spain, suggested that their mechanisms of stress tolerance are mostly based on the active transport of different ions $\left(\mathrm{Na}^{+}, \mathrm{Cl}^{-}, \mathrm{K}^{+}\right.$and $\mathrm{Ca}^{2+}$ ) to the leaves, where they contribute to osmotic adjustment, together with the synthesis and accumulation of specific compatible solutes. Our data clearly separated L. santapolense from the other three taxa, 
L. virgatum, L. giradianum and L. narbonense, as L. santapolense contains higher leaf $\mathrm{Ca}^{2+}$ concentrations and uses different compounds as functional osmolytes, namely sucrose and, to a lesser extent, glucose, which are present at very low levels in the other species. Specific morphological features of the L. santapolense root system - development of a very long taproot to reach deeper, more humid layers of the soil - explains the adaptation of this species to a drier environment than the habitats of the other three selected congeners and the apparent contradiction that $L$. santapolense was found to be the taxon most sensitive to water deficit in the greenhouse. Root morphology is a trait that should be more often considered in the studies on responses of plants to drought and salinity, as root growth is an essential functional mechanism of adaptation of plants to their natural environments.

Acknowledgements This research was partly supported by the project AICO/2017/039 from Generalitat Valenciana. We are indebted to Dr. Inmaculada Bautista (Universitat Politècnica de Valencia, Spain) for her useful suggestions for improving the manuscript.

\section{References}

Aghaleh M, Niknam V, Ebrahimzadeh H, Razavi K (2009) Salt stress effects on growth, pigments, proteins and lipid peroxidation in Salicornia persica and S. europaea. Biol Plant 53: 243-248

A1 Hassan M, López-Gresa MP, Boscaiu M, Vicente O (2016) Stress tolerance mechanisms in Juncus: responses to salinity and drought in three Juncus species adapted to different natural environments. Funct Plant Biol 43:949-960

A1 Hassan M, Estrelles E, Soriano P, López-Gresa MP, Bellés JM, Boscaiu M, Vicente O (2017) Unraveling salt tolerance mechanisms in halophytes: a comparative study on four Mediterranean Limonium species with different geographic distribution patterns. Front Plant Sci 8:1438. https://doi. org/10.3389/fpls.2016.00473

Alarcon JJ, Morales MA, Torrecillas A, Sánchez-Blanco MJ (1999) Growth, water relations and accumulation of organic and inorganic solutes in the halophyte Limonium latifolium $\mathrm{cv}$. Avignon and its interspecific hybrid Limoniun caspia $\mathrm{x}$ Limonium latifolium cv. Beltlaard during salt stress. J Plant Physiol 154:795-780

Allen RG, Pereira LS, Raes D, Smith M (1998) Crop evapotranspiration - guidelines for computing crop water requirements.
FAO irrigation and drainage paper 56. Rome, Italy: Food and agriculture Organization of the United Nations

Alvarez-Flores R, Nguyen-Thi-Truc N, Peredo-Parada S, Joffre R, Winkel T (2018) Rooting plasticity in wild and cultivated Andean Chenopodium species under soil water deficit. Plant Soil 425:479-492

Álvarez-Rogel J, Hernández J, Ortiz Silla R, Alcaraz F (1997) Patterns of spatial and temporal variations in soil salinity: example of a salt marsh in a semiarid climate. Arid Soil Res Rehabil 11:315-329

Álvarez-Rogel J, Alcaraz Ariza F, Ortiz Silla R (2000) Soil salinity and moisture gradients and plant zonation in Mediterranean salt marshes of Southeast Spain. Wetlands 20:357-372

Antonelli-Ushirobira TM, Blainski A, Gancedo NC, Gaburo F, Cardoso KAK, Leite-Mello EVD, Milaneze-Gutierre MA (2015) Morpho-anatomical study of rhizome of Limonium brasiliense. Rev Bras 25:320-327

Barbier EB, Hacker SD, Kennedy C, Koch EW, Stier AC, Silliman BR (2011) The value of estuarine and coastal ecosystem services. Ecol Monogr 81:169e193

Bates LS, Waldren RP, Teare ID (1973) Rapid determination of free proline for water stress studies. Plant Soil 39:205-207

Blainski A, Lopes GC, de Mello JCP (2013) Application and analysis of the Folin Ciocalteu method for the determination of the total phenolic content from Limonium brasiliense L. Molecules 18:6852-6865

Bouyoucos GJ (1962) Hydrometer method improved for making particle size analysis of soils. Agron J 54:464-465

Bresler E, Dagan G, Hanks RJ (1982) Análisis estadístico del rendimiento de cultivos bajo riego de fuente de línea controlada. Soil Sci Soc Am J 46:841-847

Del Rio D, Stewart AJ, Pellegrini N (2005) A review of recent studies on malondialdehyde as toxic molecule and biological marker of oxidative stress. Nutr Metab Cardiovasc Dis 15: 316-328

Demiral T, Türkan I (2005) Comparative lipid peroxidation, antioxidant defense systems and proline content in roots of two rice cultivars differing in salt tolerance. Environ Exp Bot 53: 247-257

Dubois M, Gilles KA, Hamilton JK, Reberd PA, Smith F (1956) Colorimetric method for determination of sugars and related substances. Anal Chem 28:350-356

Eber W, Veenhuis B (1991) Natalität und Mortalität bei Limonium vulgare. In: Schmid B, Stöcklin J (eds) Populationsbiologie der Pflanzen. Birkhäuser, Basel, pp 62-73

Erben M (1993) Limonium Mill. In: Castroviejo S et al (eds) Flora Ibérica 3. Real Jardín Botánico, CSIC 2-143, Madrid

Falchi M, Bertelli A, Lo Scalzo R, Morassut M, Morelli R, Das S, Cui J, Das DK (2006) Comparison of cardioprotective abilities between the flesh and skin of grapes. J Agric Food Chem 54:6613-6622

Ferriol M, Pérez I, Merle H, Boira H (2006) Ecological germination requirements of the aggregate species Teucrium pumilum (Labiatae) endemic to Spain. Plant Soil 284:205-216

Fita A, Alonso J, Martínez I, Avilés JA, Mateu MC, RodríguezBurruezo A (2013) Evaluating Capsicum spp. root architecture under field conditions. Breakthroughs in the genetics and breeding of Capsicum and eggplant (Proceedings of the 15 Eucarpia meeting) 373-376

Fitter AH (1987) An architectural approach to the comparative ecology of plant root system. New Phytol 106:61-77 
Flowers TJ, Colmer TD (2008) Salinity tolerance in halophytes. New Phytol 179:945-963

Flowers TJ, Yeo AR (1986) Ion relations of plants drought and salinity. Aust J Plant Physiol 13:75-91

Franco JA, Vicente MJ, Bañon S, Miralles J (2011) Root development in horticultural plants grown under abiotic stress conditions - a review. J Hortic Sci Biotechnol 86:543-556

Fry EL, Evans AL, Sturock CJ, Bullock JM, Bradgett RD (2018) Root architecture governs plasticity in response to drought. Plant Soil 433:189-200

Giacobbe A (1938) Schema di una teoria ecologica per la classificazione della vegetatione italiana. Nouvo Giornale Botanico Italiano 45:37-121

Giacobbe A (1959) Nouvelles recherces écologiques sur l'aridité dans les pays de la Méditerranée occidentale. Nat Monsp 11: $7-28$

González-Orenga S, Al Hassan M, Llinares JV, Lisón P, LópezGresa MP, Verdeguer M, Vicente O, Boscaiu M (2019) Qualitative and quantitative differences in osmolytes accumulation and antioxidant activities in response to water deficit in four Mediterranean Limonium species. Plants 8(11): 506

Greuter W, Burdet HM, Long G (1989) Med-checklist. In: Genève. Conservatoire et Jardin Botaniques de la Ville de Genève, Genève

Grieve CM, Grattan SR (1983) Rapid assay for determination of water soluble quaternary ammonium compounds. Plant Soil 70:303-307

Grigore MN, Toma C (2017) Definition and classification of halophytes. In: Grigore MN, Toma C (eds) Anatomical adaptations of halophytes. A review of classic literature and recent findings. Springer International e-book 3-28, New York

Hadi MR, Karimi N (2012) The role of calcium in plants' salt tolerance. J Plant Nutr 35:2037-2054

Hameed A, Gulzar S, Aziz I, Hussain T, Gul B, Khan MA (2015) Effects of salinity and ascorbic acid on growth, water status and antioxidant system in a perennial halophyte. AoB Plants 19:7. https://doi.org/10.1093/aobpla/plv004

Hanson DA, Rathinasabapathi B, Chamberlin B, Gage DA (1991) Comparative physiological evidence that $B$-alanin betaine and choline-O-sulfate act as compatible osmolytes in halophytic Limonium species. Plant Physiol 97:1199-1205

Hasegawa PH, Bressan RA, Zhu JK, Bohnert HJ (2000) Plant cellular and molecular responses to high salinity. Annu Rev Plant Physiol Plant Mol Biol 51:463-499

Hazelton PA, Murphy BW (2007) Interpreting soil test results: what do all the numbers mean? 1 CSIRO Publishing, Melbourne

Hill MO, Preston CD, Roy DB (2004) PLANTATT - attributes of British and Irish plants: status, size, life history, geography and habitats. Centre for ecology and hydrology, Huntingdon

Hodges DM, De Long JM, Forney CF, Prange RK (1999) Improving the thiobarbituric acid-reactive- substances assay for estimating lipid peroxidation in plant tissues containing anthocyanin and other interfering compounds. Planta 207: 604-611

IGME (1973). Mapa geológico de Elche (Hoja 893). Available at http://info.igme.es/cartografiadigital/geologica/Magna50 Hoja.aspx?Id=893. Accessed 20 Nov 2019
IGME (1974). Mapa geológico de Valencia (Hoja 722). Available at http://info.igme.es/cartografiadigital/geologica/Magna50 Hoja.aspx?Id=722. Accessed 20 Nov 2018

Leng BY, Yuan F, Dong XX, Wang J, Wang BS (2018) Distribution pattern and salt excretion rate of salt glands in two recretohalophyte species of Limonium (Plumbaginaceae). S Afr J Bot 115:74-80

Liu X, Grieve C (2009) Accumulation of chiro-inositol and other nonstructural carbohydrates in Limonium species in response to saline irrigation waters. J Am Soc Hortic Sci 134:329-336

Magalhães TM, Seifert T (2015) Below- and aboveground architecture of Androstachys johnsonii Prain: topological analysis of the root and shoot systems. Plant Soil 394:257-269

Mateo C, Crespo MB (2014) Claves Ilustradas para la Flora Valenciana. Jolube Consultor y Editor Botánico, Jaca

Monllor M, Soriano P, Llinares JV, Boscaiu M, Estrelles E (2018) Assessing effects of temperature change on four Limonium species from threatened Mediterranean salt-affected habitats. Not Bot Horti Agrobo 46:286-291

Nawaz K, Ashraf M (2010) Exogenous application of glycinebetaine modulates activities of antioxidants in maize plants subjected to salt stress. J Agron Crop Sci 196:28-37

Prieto I, Padilla FM, Armas C, Pugnaire FI (2011) The role of hydraulic lift on seedling establishment under a nurse plant species in a semi-arid environment. Perspect Plant Ecol 13: $181-187$

Rhoades JD (1982) Cation exchange capacity. In: Page AL (ed) Methods of soil analysis. Part 2: chemical and microbiological properties, 2nd edn, pp 149-157

Rivas-Martínez S, Rivas-Saenz S (1996-2018) Worldwide bioclimatic classification system, Phytosociological Research Center, Spain. Available at http://www.globalbioclimatics. org. Accessed 20 Nov 2018

Sagar B, Kedare B, Singh RP (2011) Genesis and development of DPPH method of antioxidant assay. J Food Sci Technol 48: 412-422

Schmidt JE, Gaudin ACM (2017) Toward an integrated root ideotype for irrigated systems. Trends Plant Sci 22:433443

SIAR (Sistema de Información Agroclimática para Regadío) (2018). Benifaio and Elx agro-meteorological stations. Available at http://www.magrama.gob.es/es/agua/temas/observatorio-delregadio-espanol/sistema-de-informacion-agroclimatica-parael-regadio/. Accessed 15 Jan 2019

Soil Survey Division Staff (1993) Soil survey manual. USDA. Handb. No. 18. GPO, Washington, DC

Suzuki N, Mittler R (2006) Reactive oxygen species and temperature stresses: a delicate balance between signaling and destruction. Physiol Plant 126:45-51

Suzuki JI, Stuefer JF (1999) On the ecological and evolutionary significance of storage in clonal plants. Plant Spec Biol 14: $11-17$

Thorne KM, Takekava JY, Elliot-Fisk DL (2012) Ecological effects of climate change on salt marsh wildlife: a case study from a highly urbanized estuary. J Coast Res 28(6):14771487

Walkley A, Black IA (1934) An examination of the Degtjareff method for determining soil organic matter and a proposed 
modification of the chromic acid titration method. Soil Sci 37:29-38

Weimberg R (1987) Solute adjustments in leaves of two species of wheat at two different stages of growth in response to salinity. Physiol Plant 70:381-388

Wyn-Jones RG, Gorham J (2002) Intra- and inter-cellular compartmentation of ions. In: Läuchli A, Lüttge U (eds) Salinity: environment - plants - molecules. Kluwer Academic Publishers, Dordrecht, pp 159-180

Yáñez J (1989) Análisis de suelos y su interpretación. Horticultura 49:75-89
Zhishen J, Mengcheng T, Jianming W (1999) The determination of flavonoid contents in mulberry and their scavenging effects on superoxide radicals. Food Chem 64:555-559

Zia S, Egan T, Khan MA (2008) Growth and selective ion transport of Limonium stocksii under saline conditions. Pak J Bot 40:697-709

Publisher's note Springer Nature remains neutral with regard to jurisdictional claims in published maps and institutional affiliations. 